\title{
Humanitarian Settings for Syrian Refugees: Understanding The History of Syria Civil War
}

\author{
Xiaotong Liang a \\ Labor and Social Security, Lanzhou University of Finance and Economy, Lanzhou, China \\ a1464584618@qq.com
}

\begin{abstract}
As it is known to all, the Syria Civil War broke out in 2011. Till today, the war has lasted for about ten years. Because of the blooded war, plenty of Syrian fellow citizens have become refugees who lost their applications, families, and lives. Most of the people who have survived have fled to Turkey and other Mediterranean countries. The survey from the official website of UNHCR, as of 2019, Syria had 6.6 million refugees (UNHCR, year).[1] Behind this incredible number is the essential embodiment of contemporary international political patterns' uncertainty. The primary reason for refugees emerging has a relationship with the war. The global way of "one super strong" leads to the constant disputes between the world's great powers and local conflicts become an essential means for the great powers to compete for domination. As an actual battlefield of the Proxy War, an in-depth study of Syria is conducive to a better understanding of the consequences of the Syrian Civil War and the emerging factors and solutions and future development of Syrian refugees. This essay includes several main sections, the introduction of the Syrian civil war, what factors lead to the emergence of Syrian refugees, the prediction of the future of Syrian refugees, the full summary from the macro-level to interpret the humanitarian environment where Syrian refugees go. Based on the existing research materials and the actual situation, the purpose of this paper is to understand the current status of refugees and the relevant relief measures of current UNHCR and host countries and to appeal to the people of the world to pay typical attention to the problem of refugees and try our best to help the Syrian refugees out and give them a warm home.
\end{abstract}

Keywords: Humanitarian Settings, Syria Civil War, Syrian refugees, refugees assistance measures.

\section{INTRODUCTION}

The Syria Civil War is that the conflict between the Syrian government and the Syrian opposition organization, the Islamic State, which has continued for a long time since the beginning of 2011 and antigovernment demonstrations in Syria began on 26 January 2011 and escalated on 15 March, followed by armed clashes.[2] With the intervention of regional and Israeli powers, the situation in Syria ranges from demonstrations to armed conflicts, from the emergence of the "Free Syrian Army" to the emergence of the "Islamic State", and finally forms a situation of hybrid warfare and seizure of hills by Syrian government forces, armed opposition forces, and armed extremist organizations.[3] The Civil War has made Syria the bloodiest territory in the Middle East, widening ethnic and sectarian rifts in Syria, leading to "jihad" forces, and the spillover of several significant issues: refugees, geopolitical rivalry, violent conflict, which has resulted in the Middle East volatile situation. Undoubtedly, refugee spillover is the most obvious negative impact of the civil war. According to some official profiles, a refugee's definition is that a person on a proven ground fears persecution and remains outside their own country for various reasons. Besides, this fear cannot eliminate by that country or unwilling to return to that country.[4] Looking at figure 1, Until 2019, Syria had 6.6 million refugees, with about $60 \%$ of Syrian refugees being inadequate.[5] The Syrian refugees have put significant pressure on the limited energy and water resources. Besides, refugees' coming also has had a substantial adverse effect on host countries' social infrastructure and economic development. Based on the principle of keeping international order stable and promoting human beings' sustainable development, the refugee problem's solution requires multiple bodies' participation. The refugees who flee the nation because of civil war have several kinds of groups: voluntary repatriation, retention in host countries, and resettlement.[6] International organizations and host countries should take appropriate pacification measures to treat different refugees according to the actual situation. War is the root cause of refugees that we should stop launching war and promote peaceful development based on humanitarianism. For example, in December 1953, the Chinese Government and the Indian Government held negotiations on the relationship between the two countries in Tibet. During the meeting with the Indian 
delegation, Premier ZhouEnlai, the representative of China, for the first time, put forward the five principles of peaceful coexistence: mutual respect for sovereignty and territorial integrity, non-aggression, non-interference in each others' internal affairs, equality, and mutual benefit, and peaceful coexistence,[7] which immensely helped to the current relationship between countries in the world at present.
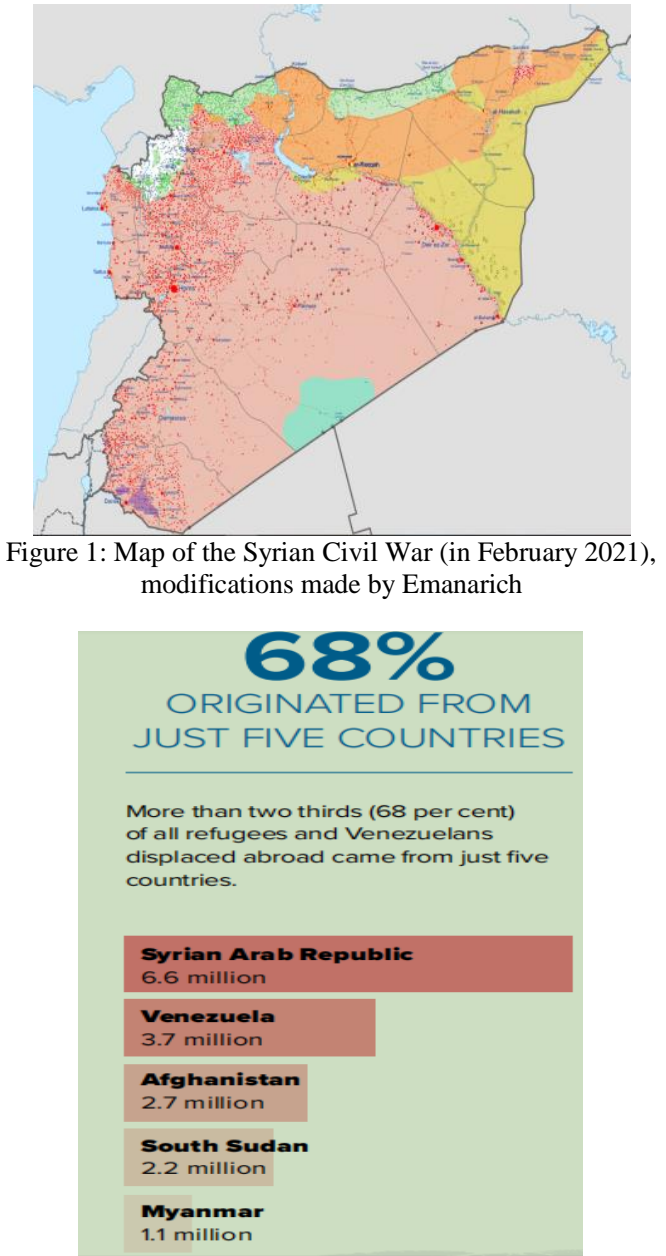

Figure 2: The figure of refugees in leading countries in 2019. UNHCR(2019), TRENDS AT A GLANCE, page2

\section{THE HISTORY OF SYRIA CIVIL WAR}

Various factors cause the causes of the outbreak of civil war in Syria. Internal factors can be divided into economic weakness and political mess. External factors include military invasion, diplomatic dilemma, religious conflict, and geopolitics.

In terms of internal factors, at first, economically: Most of the Syrian territory is a northwest-southeast inclined plateau, and the country has several geographical zones: the western mountains and the mountain valley between the two mountains, also including the highest sea level of 2841 meters which locates nearby the Sheikh Mountain. The northwest Mediterranean coastal plain, with a $183 \mathrm{~km}$ coastline, is a few green places in the country, and the available land resources are incredibly scarce. Syria is relatively dry, with less rainfall in the whole year, which means fewer water resources. We can see that agriculture is the most critical industry for national development. The level of land development in Syria is low, the level of agricultural technology is standard, agricultural product's extra value is tiny, and the economy's development is slow. In industry, Syria's industrial base is weak, the primary economy type is the state-owned economy, and the modern industry's development is only decades.[8]

Then, politically: Syria's domestic regime is unstable. The regime's factional struggle is complicated, and the turbulent social environment breeds terrorism (ISIS) and combines with the domestic opposition to undermine social order. At the same time, Bashar's dominant Syria is extravagant, imposing capital punishment on domestic opponents and intensifying social contradictions. In 2011, a key piece of news: in March 2011,15, police caught the teenagers after painting anti-government graffiti on Bashar's extravagance walls. Visible Syrian nationals to the government produced a more fabulous negative mood, which indirectly led to civil war emergence.

Syria Civil War broke out not only with its factors but also had crucial external factors. First of all, we can start with the geography of Syria. Syria's civil war has a solid geopolitical character — Syria is located on the eastern Mediterranean coast, bordering many countries, such as Iraq, Israel, Lebanon, which has led to its complex and changeable international relations — the importance of neighboring relations. Meanwhile, Syria had affluent oil and gas resources and was on the vital oil transportation route. Strengthened the world's significant powers, it took a right to exploit cheap natural resources economically and took political control of the Middle East region. It strengthened the strength and made military strikes against other major powers, thus using their own identity to interfere with the Syrian civil war. Secondly, we can talk about the military: when World War II ended, the world formed a "one super country and many strong countries" political pattern — the United States is the only world superpower. China, Russia, and other countries, all of them became the world's strong powers. Outstanding power disputes have always existed, among which interference in other countries internal affairs is one of the main manifestations of excellent power hegemony. To illustrate this view, we can use the Post War to illustrate two countries with opposite ideologies, the USA and the USSR, with total national power. The same goal they had was being the "leader" of the world, so they engaged in an arms race and launched a local war (the war between Iran and Iraq), and the Middle East became the leading "competition ground. History has proved that the rise of great powers and sovereignty must be inseparable from war: in ancient times, ancient Rome launched three Punic wars to defeat Carthage and capture the supremacy of the western Mediterranean. In modern times, Britain launched a seven-year war in the 18th century to challenge Spanish hegemony and rapidly 
expand its colonies after defeating Spain to become an "Empire". As we all know, Syria is a bridgehead and forward base south of Russia. If Russia controls Syria, it can control the Mediterranean Sea, the Middle East, and Africa, and retreat can guard the Black Sea. So Syria has to protect, or Russia's dominant area will limit in the Black Sea, the Black Sea fleet will lose its crucial function of protecting the route from the Russian mainland to the Mediterranean Sea. Therefore, the only country in the Middle East where Russia has a military base in Syria, and South Russia has a Black Sea fleet. As long as Russia stabilizes Syria, Russia holds important positions in the Mediterranean Sea to ensure that the Black Sea fleet can reach the Mediterranean Sea. Based on this position, to gain their interests from the Syrian government has been Russia's key support group. Simultaneously, the attack on the opposition in Syria is also an important manifestation of Syria's stability. Moreover, the United States, too, to keep their interests, weaken Russia's internship, launched a "Proxy War". Most people know that most of the main religions are born in the Middle East, and regional conflict is greatly affected by religious disputes. In terms of religion, the people from Israel believe in Judaism while the people from Arab countries believe in Islam. There are plenty of factions in Islam divided into different Arab countries because of history, and both Sunni and Shiite have huge reputations in Islam. The complex sectarian strife within Islam has become a "favorable basis" for the great powers to interfere in their internal affairs to compete for supremacy and provides a reasonable reason for launching proxy wars. The ruling class led by Basar is like Iran. The majority in Syria is Sunni. There is no doubt that national policies' fundamental point is to achieve benefits maximization. A high degree of unity of thought and belief will become a tremendous driving force for war. Thus, a consistent religious faction will become an excellent reason for cooperation between different interest groups. On the contrary, factional differences will also become an excuse for interest groups to oppose. Since the last century, Because of the contractions in policies, military, and other areas, the United States has a tense relationship with Iran. Iran's research and development of nuclear weapons led to the United States' dissatisfaction. Iran has become the United States' focus in Western Asia to crack down and blockade the object. Furthermore, because of factional reasons, Iran and the Sunni countries led by Saudi Arabia have long been hostile. The ruling class is Sunni and Iran and Russia's long-term cooperative relations, Iran and Syria are better relations. Therefore, for opponents and other national interest factors, the great powers will also use religious differences to participate in the civil war. As it is known to all, weak States have no diplomacy, which means that its comprehensive national strength determines a country's right to speak in the international community. Syria, whether in its national territory or its economy or soft power, it hardy become a superpower like the United States and China because of weak productivity. Therefore, Syria has no choice but to become a political game tool for great powers. After the Iran-Iraq War, Syria was put on the "blacklist" of the United States because of its political position and interest differences with the United States. Also, it became the United States' enemy.

Russia cannot retreat, and it will have no discourse power in the Mediterranean without keeping the Syrian Assad regime. To preserve the vital ground in Russia's Middle East position, Putin has given tremendous financial support to Syria's economic development but has also become enemies of some big powers. However, the United States, Turkey, Saudi Arabia, and other countries began to scramble to provide arms support for Syrian opposition forces. As a result, Syria, which has not easily seen the dawn of peace, is again involved in the war. Under the combined action of internal and external factors, the outbreak of civil war in Syria was also an inevitable result, and because of that, refugees had also emerged.

The Syrian civil war has lasted for a long time. Until today, Syria is an important "target" for the United States. Let us see figure 3: on February 25, 2021, at local time, President Biden issued the first military order in his term, ordered to launch airstrikes against Iranian-backed militias in Syria.[9] President Joe Biden has approved artillery fire across eastern Syria, targeting Iranianaffiliated militias at several facilities. Focusing on picture3, during the military strike, the United States dropped seven GBU-38 joint direct attack bombs on seven targets of cross-border weapons delivery by militia groups in Syria. These bombs are deadly, causing severe damage to the country's houses and other infrastructure. Figure 4 vividly shows that the places and the local region were seriously ruining. On 10 March 2021, Guterres said that the international community must continue to provide Syria with additional necessary humanitarian assistance. "Nowadays, Syria is still in a pessimistic situation, "Guterres told a news conference on the 10th anniversary of the crisis at United Nations Headquarters in New York. For ten years, the world has seen Syria plunged into a whirlpool of destruction and bloodshed." Since the onset of the crisis, many Syrian people have died and lost their homes. The civil war's adverse effects seem to be more and more serious. 


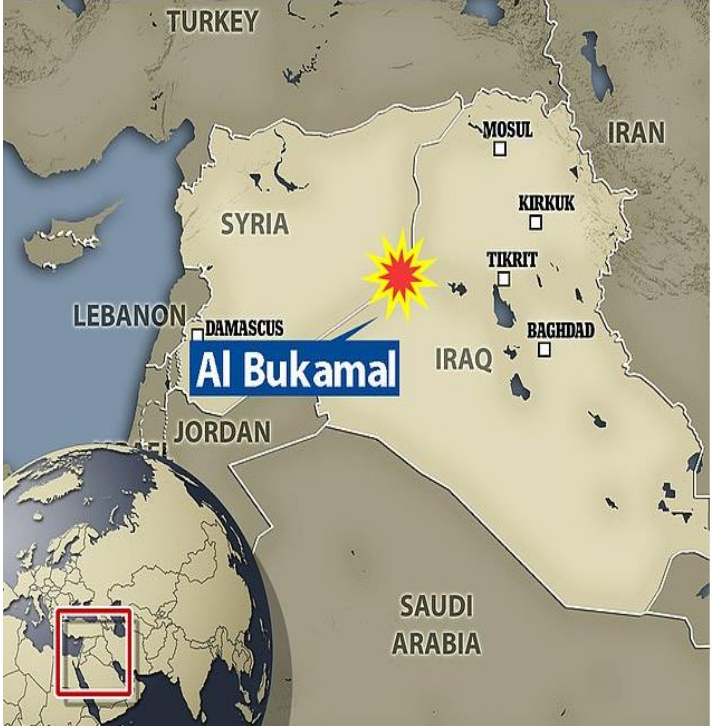

Figure 3:It has reported that the U S. airstrikes targeted pro-Iranian militias' facilities in Abu Kamal, eastern Syria. Source: Dailymail

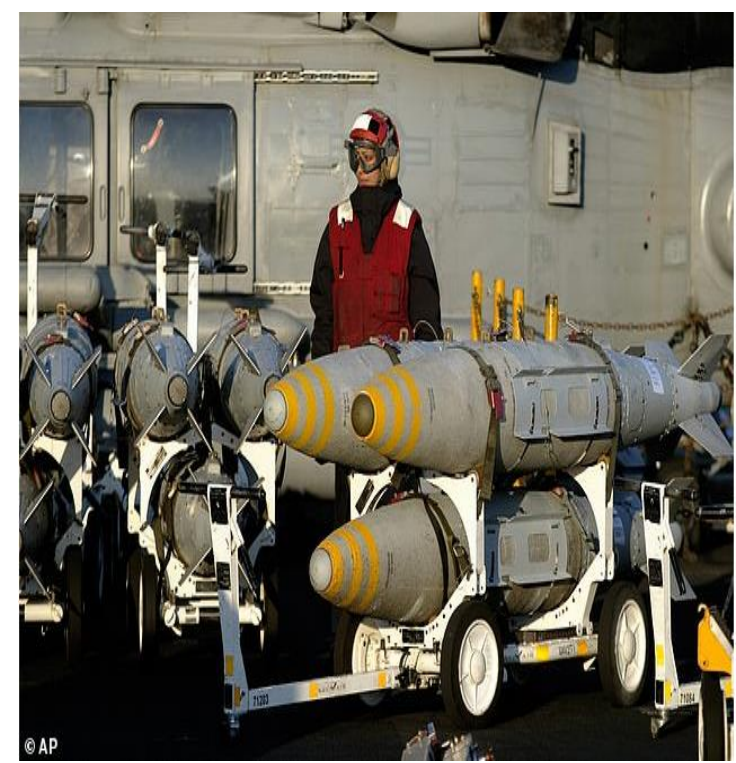

Figure 4: The United States dropped seven GBU-38 joint direct attack bombs against seven targets of militia groups transporting weapons across the border (JDAM). Source: Dailymail

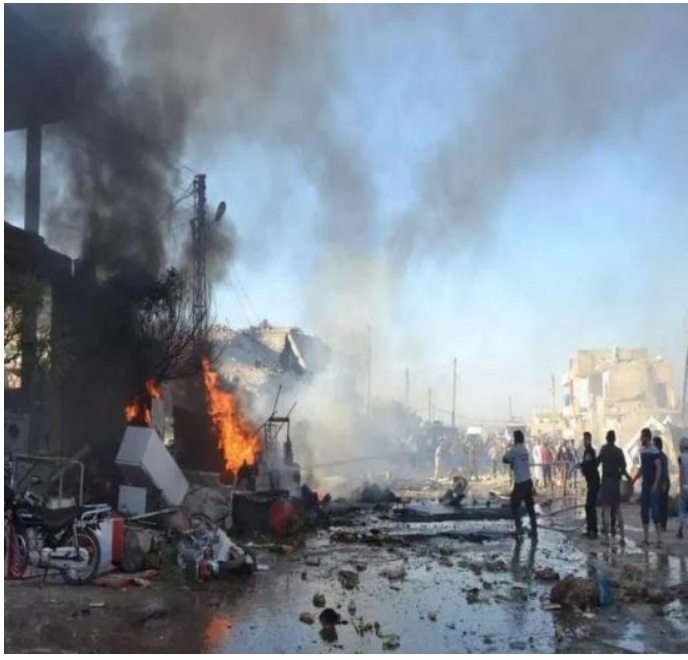

Figure 5:War-torn Syria. Source: Tencent News (20213-8)

\section{CAUSES OF THE ORIGIN OF REFUGEES}

The outbreak of civil war is the fundamental factor of refugees' plenty of aspects. In the last century, the outbreak of World War II led to the displacement of many Jews. In this century, the Syrian civil war reflected that refugees were the negative consequences of the war. At the end of February 2021, a coordinator told the Council's online briefing on the situation in Syria that over the past 18 months, Syria's fragile economy had "suffered multiple shocks", with its currency plummeting, unemployment rising, and basic needs unmet.[10]

First of all, the most prominent and direct result of war is the destruction of the economic system. In the era of hot weapons, the investment of missiles and other weapons made the available land in the war area disappear. In this area, comprehensive factors reduced farm products that the agriculture stood in paralyzation, food was in short supply. Meanwhile, the UN's undersecretary-general for humanitarian affairs and emergency relief coordinator notes that Syria's average household spending is now about $20 \%$ higher than income and that millions have to survive through desperate measures.

Second, war can also lead to political instability and social unrest. Undoubtedly, one of the negative consequences of wars is economic collapse just Because the essential living criteria are rigid to guarantee. The violence rate will rise, public order will fall, and security will promise that refugees emerge.

The problem of refugees was a matter for the longterm development of the international community. When refugees with no way to escape were desperate and forced to commit crimes, it affects the security of host countries and brings a pessimistic effect on neighboring countries. Suppose we can adequately resolve the religious and cultural conflicts between refugees and host countries and resettle the refugees upon arrival in host countries 
suitably. In that case, they can be a burden and become the driving force for developing their host countries and making an outstanding contribution to the economy.[11]

\section{THE FUTURE OF SYRIA REFUGEES}

\subsection{UNHCR MEASURES TO ASSIST REFUGEES}

Because of a long time of the civil war, the refugee problem has existed for many years. The continuous deterioration of the Syrian refugee problem is rooted in the bullying and wanton interference of several great powers. Suppose we genuinely cope with the refugee problem. In that case, the political system should be fully independent and do not have interference power, and make every effort to improve Syria's economic and humanitarian situation.[12]

UNHCR is a vital institution in assisting refugees worldwide, that refugee protection is at the heart of the UNHCR mandate. It includes providing safety for refugees not to be easy to return to dangerous situations, providing them access to fair and efficient asylum procedures, and ensuring their human rights are protected. At the same time, they secure a long-term solution for a safe future.[13] For assisting measures, UNHCR always obeys the basic principles of terrorism sovereignty and refugee rescuing: the survival security principle, the attitude of trust, friendliness, and help to refugees, respect for refugees, material support for refugees, and spiritual encouragement. The direction of minimum living needs should be guaranteed, the standard of relief should be accurately grasped, and the actual situation of refugees should be thoroughly investigated and analyzed, and the guaranteed standard should be reasonably determined, which should not only guarantee the minimum standard of living of refugees but also arouse the enthusiasm of refugees for hard work. Based on the principle of continuous adjustment, the relief of refugees will be sustainable, so the standard of protection should be constantly adjusted according to the level of their own development and the level of local prices, such as CPI. And the principle of legalization should have clear regulations on the scope, standard, source of funds, and management system of relief, so as to enhance the stability, systematization, and authority of the relief work. At the same time, it is necessary to clarify that obtaining relief is a legal right of refugees and eliminates the gift and compassion of relief measures.

As we all, measured data is a vital tool of helpful relief. Therefore, when giving refugees a hand, the UNHCR is to undertake a comprehensive needs assessment of refugees. Key measures could include: a helpful review needs information on age, gender, values, and vulnerabilities of different groups, families, and individuals in the refugee population as the main criteria. Staff doing an excellent job of refugee registration and data collection, ensuring that refugees have valid documentation and that individual case files are stored safely, with full respect for the identity of the registrant and regular updating of information. Regular monitoring of the health, nutritional status, living conditions, and general welfare of urban refugees to ensure that these are not below acceptable standards. The high accuracy and authenticity of the data will facilitate the UNHCR of improving the accuracy of the match between refugee demand and supply, improving program objectives and budgetary tasks, and determining the actual needs of refugees, as well as the cost of meeting them and the consequences of any funding gap arising from their demands; vulnerabilities, requirements, and abilities, which data collection includes. What is more, they can effectively help refugees acquire basic rights. When enabling UNHCR to collect accurate data on the urban refugee population, UNHCR can better identify refugees with immediate and specific needs. Next, facilities construction also needs objective budgeting evaluation data. Finally, it is a good idea to provide documentation to persons of concern to UNHCR for the early identification and protection of refugees. Simultaneously, the reduction of the administrative burden should keep the feet updated.

Then, the refugees should have equal rights to enjoy the best possible infrastructure. Specific practices include comprehensive reception arrangements for refugees seeking direct access to UNHCR, provision of adequate facilities in waiting rooms and reception areas in urban areas. It means that the assisting facilities should have clean water to drink, sufficient shade or heating, and give the disabled people a hand. Legal and social counseling and trained interpretation services for refugees and asylum-seekers when in contact with UNHCR are necessary. We can see that the reception measures have rapid development while facilitating refugees' asylumseeking, making the staff efficiency improve and reducing work pressure. They can reduce the waiting time of refugees at UNHCR, limit the number of agglomerations, and reduce the likelihood of COVID-19 outbreaks.

Also, UNHCR can expand the range of protection and insist on a complete protection strategy. We can use the method to imagine that if the scope of protection is too small and the supply of urban infrastructure is less than demand, it will negatively affect public goods' need is vastly higher than the supply of the public interests. At the same time, comprehensive protection can effectively avoid establishing separate and parallel services for its donors, effectively using limited local resources, and can also greatly encourage the authorities and residents to recognize the additional funding of urban refugees, encourage refugees to prioritize their own needs and provide realistic expectations of UNHCR assistance capacity to help UNHCR to deliver more targeted relief. The following effective measures are UNHCR in this 
regard: refugees have the right to move freely, association, and expression, UNHCR has to protect their family reunification. The organizations and the host countries must help the refugees find good-paying applications on the labor market to earn their livings and prevent them from getting exploited by landlords, and businessmen, and employers. To help refugees have legal and safe residency rights and obtain official documentation; to help refugees enjoy some services just like a free body check and so on. To help refugees maintain harmonious relations with host populations, migrant citizens, and other nation refugees in the communities. UNHCR uses its "high-risk identification tool" to assist urban refugee communities in selection and agreement. UNHCR strengthens existing fully mandated delivery systems with host governments. If the refugees cannot pursue secure and productive lives elsewhere, some refugees will inevitably feel compelled to move to an urban area, even if they are not formally allowed. Chaotic immigration will increase the number of urban refugees seeking support from UNHCR and other actors, place additional pressures on scarce services and resources may let the tensions between refugees and the local citizens break out.[14] Besides, it is an obvious fact that most refugees hardly live in a fixed place, and they move frequently, so expanding the scope of protection can better protect refugees. When refugees take up residence in an urban area, whether or not the authorities approve this, UNHCR's primary objective will be to preserve and expand the amount of protection space available to them and to the humanitarian organizations that are providing such refugees with affordable access to protection and help.[15]

Establishing efficient communication mechanisms with refugees is an essential responsibility of the UNHCR. Many specific measures can be referred to as the regular staff assignment to visit and talk to refugees. The enhancement of communication with refugees is abundant. For example, they use mobile registration teams to contact refugees in the homes and communities. What is more, UNHCR puts much effort into collecting refugees' information by posting posters in a community center and other places that refugees gather. Also, widely disseminate itinerary registration information by the website and other social media is a good idea to have deep talks with refugees for the institution's staff. Good communication between international organizations and refugees facilitates UNHCR access to urban refugees and ensures that they understand their rights and obligations and their opportunities and services. What is more, many UNHCR staff who have worked with refugee camps for many years may lack the skills required to conduct practical outreach activities in urban areas. They may not be familiar with working with municipal and local government agencies. Effective communication can help staff better understand the relevant policies of host governments from the refugees living in the local region, and effective communication can help the team perform better.

To ensure the effectiveness of refugee assistance, strengthening practical cooperation with other international organizations is necessary. In the area of international collaboration: UNHCR in partnership with UNICEF to establish child-friendly spaces in reception areas; the UNHCR ought to actively cooperate with various international organizations such as UNICEF, WTO and other vital institutions to share the private information of the refugees so that they can make better decisions for assisting refugees.[16] And they should have a good relationship with other UN teams, and the NGO community, and the Red Cross and Red Crescent Movement.[17] To contribute actively to urban development and world poverty eradication, full cooperation can effectively increase the capacity of existing public and private services and ensure that refugees who seek refuge in cities receive comprehensive assistance such as health care and education.

Whether the features of organizations are regional or international, the efficient operation of organizations cannot be separated from the high discipline of the group members. As a result, in addition to the high level of concern for refugees' pacification, within the UNHCR, strengthening UNHCR staff to be bound by a code of conduct is an essential step towards strengthening the workforce. UNHCR encourages refugees to submit their complaints, concerns, and recommendations to UNHCR through confidential, free access, and transparent and open mechanisms. Such external monitoring initiatives can effectively curb abuse, exploitation, or corruption, improve UNHCR work quality, and create an excellent external image. Simultaneously, strict staff requirements are also conducive to implementing UNHCR service objectives and improving the overall quality of UNHCR staff. In the internal management, the staff with reasonable standards for regular inspection should reward them for their visible efforts to raise their spirit to work more effectively if they perform very well. To punish the staff with bad results and urge them to improve their work quality and efficiency.

Whether it is UNHCR financial assistance to refugees or other material assistance, this external assistance is simply a drop in the bucket. It cannot address the root causes of refugee resettlement. The necessary social service had a significant positive impact on refugees. The main problem facing refugees was how to survive, but at the same time, it was difficult for them to overcome it through their efforts. The most effective way to solve refugees' difficulties is to implement social assistance policies and improve their survival ability. So, suppose the refugee problem is to be solved completely. In that case, it is necessary to start from the refugees themselves, which is also the most critical measure that UNHCR needs to do: developing self-reliance. The reasons why 
we should think highly of these measures are that we can believe in reverse: in efforts to build sustainable livelihoods, urban refugees often face a wide variety of legal, financial, cultural, and linguistic barriers, such as differences between the mother tongue of refugees and the official language of host countries, which prevent them from communicating with the local population. In many cases, they have no choice but to join the informal economy to survive, such as smuggling. In the informal economy, they compete with large numbers of poor locals for dangerous and low-paid jobs. Because most companies pursue the maximization of benefits and minimize costs, they choose to hire refugees rather than nationals. So, many refugees will become "cheap labor". However, if the companies are not affected by unfair treatment alone, they are unlikely to file complaints or seek redress with the governments or international organizations. At the same time, if they cannot support themselves legally, some refugees may be involved in illegal and degrading activities. They may also go to other countries unlawfully, such as smuggling or returning to their mother countries prematurely.[18] Therefore, it is necessary to help refugees improve their ability and acquire the skills to survive.

Some countries do not let refugees earn their earnings through their efforts. Considering the national legal level, the UNHCR will help refugees become self-reliant in a discreet manner. UNHCR takes some effective measures to provide skills training to help refugees obtain visas and passports after several years of working freely in host countries. A typical example of this goal is introducing refugees to open small-scale and family-based enterprises. Besides, UNHCR will bring $\$ 600$ per month to refugees and family members to ensure their living level can match the standard of the lowest living criteria in the aspect of assistance. Besides, We can analyze this by focusing on the current situation that small interest-free or lowinterest loans are issued to refugees to improve their production efficiency and implement self-help production. There is no doubt that we should pay attention to the improvement of refugees' self-reliance capability, [19] and take humanitarian considerations into account,[20] for refugees who can not survive through their efforts, such as refugees with severe disabilities. They worth enjoying the most significant assistance to ensure their minimum living standards. If self-reliance is not achievable, collective accommodation centers are necessary, which provided that matching acceptable criteria, northeast subsidized housing and distributes free or subsidized food and other necessities.

Besides the above measures, UNHCR also makes more contributions in various areas. In January 2020, in Wuhan, Hubei Province, China broke out a terrible pandemic--COVID-19. In the virus spreading control aspect, the Chinese government has tried all its efforts.[21] Soon in just a few months, the Chinese government effectively controlled COVID-19, and China became the world's only growing economy by 2020 because of its unique prevention and control methods. The Chinese government has shown the world efficient prevention and control efficiency. Among them, the Chinese government takes the community as the unit to carry out the prevention and control to the individual level the data accuracy is improved and dramatically reduces the speed of epidemic spread. In refugee management, community-based management may be worth trying. Today, COVID-19 has been living with humans for more than a year. Therefore, there are plenty of adverse effects it brings to us. It has also led to a shift in people's position on refugee policy and the COVID-19 influence of Governments in policy development. Concerns remain as to whether countries will deploy the "public health" rationale for a prolonged period, resulting in temporary policies becoming indefinite ones.[22] Effective management is critical in times of COVID-19 prevalence. We believe that community-based management has the following advantages: community management will implement the policy to the most basic level of society, effectively giving fellow citizens a platform to take action, dampening citizens' enthusiasm. Besides, promoting the people to mind the refugees' settlement is also a positive effect for good management.[23] To some extent, let the residents live with refugees can better understand refugees' living habits. Simultaneously, community assistance implementation can help improve relief quality. Based on these points, UNHCR staff can reach out to and build good relationships with urban refugee communities, also develop joint strategies for community outreach and communication. When monitoring and assessing the impact of implementing partners' activities, they should establish valid complaint and accountability mechanisms, which involve refugees in program design and work under AGDM principles.[24] There is much action we can take: strengthening community service functions, encouraging positive interaction between refugees and their local owners, working to help them adapt to the new environment and combat discrimination and xenophobia, and will ensure that services provided to urban refugees benefit other urban residents, such as increasing awareness of refugee reception, granting grants to residents hosting refugees, and so on. Establishing multifunctional teams in cities with large refugee populations. Offices in urban areas are prepared to respond to local contingency plans, which in the event of a security incident may be discouraged by the lack of access to protection, solutions, and assistance and hold individual UNHCR staff accountable. Contingency plans can also guarantee staff safety while safeguarding refugees' legitimate rights and interests and maintaining urban order stability. Although there is no such measure in refugee management at present, community-based management has a distinct epoch and practicality, which accords with world disease prevention and control and construction requirements in the current epidemic period. 


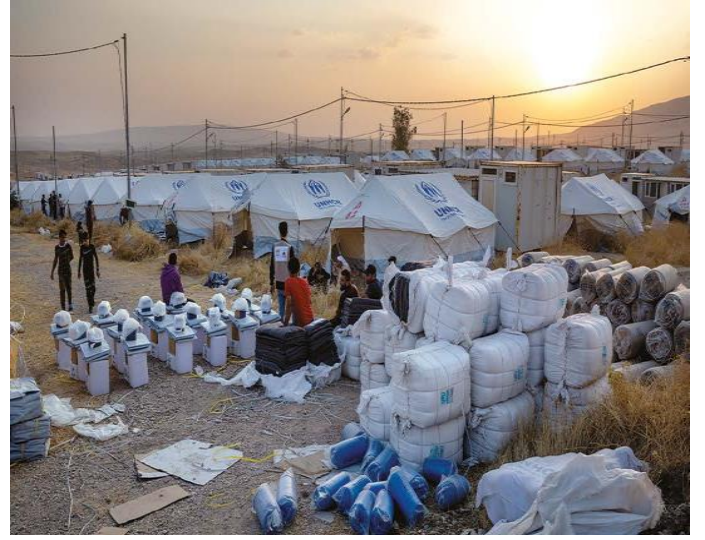

Figure 6: UNHCR dispatches aid and shelter supplies to Bardarash camp in Duhok, Iraq, for Syrian refugees fleeing the northeast of the Syrian Arab Republic. Source: UNHCR

\section{HOST COUNTRIES MEASURES TO ASSIST REFUGEES}

Apart from relying on international organizations such as UNHCR, refugees' relief and pacification require refugee host countries' joint efforts that have signed international agreements.

First of all, a refugee host country must have a sense of responsibility to develop infrastructure and work with UNHCR to solve refugee resettlement.[25] Once again, we think backward that if the public goods of the host country are unable to meet the needs of the refugees and the refugees have to move to the cities, the tendency of refugees will constantly improve, which will also increase the number of urban refugees seeking support from UNHCR and other actors and increase the pressure on public service goods. Because the host country's social environment cannot meet the refugees' needs, it is easy for the refugees to flow from the host country to other neighboring countries without permission. Therefore, this will quickly make the relationship between the refugees and the inflow country residents nervous. Besides, it will lead to the deterioration of the relationship between the two countries and increase the difficulty of relief because of the national interests threat.

Second, host Governments should take the initiative of acting as "mandate sponsors" to help a wide range of different stakeholders establish effective working relationships. The private sector, legal networks, other civil society institutions, and development agencies have excellent cooperation in policy and judiciary aspects. Multiple subjects' participation can effectively expand the scope of refugee protection power, build a refugees' protection system, reduce organizations' relief pressure, effectively improve information sharing and communication, and increase efficiency.

Besides, it is of the utmost importance that host Governments should increase their financial investment in social security and assistance, improve the overall quality of refugees through education and vocational training, impart relevant skills and knowledge to refugees and enhance their self-reliance. We can imagine that if refugees cannot obtain employment through formal channels for a long time, refugees who lack social awareness are prone to become the perpetrators of social chaos and are not conducive to society's stable development. At the same time, if the refugees can not work through their efforts for a long time, the government's fiscal expenditure will increase, the country is prone to budgetary effects deficit, also income and spending. The accompanying effect is the stress of domestic companies on tax burden will deepen further, economic vitality plummeted. Moreover, for the country's residents, refugees' arrival will undoubtedly increase domestic employment pressure and bring about a sharp decrease in social security and social welfare, leading to an increase in unemployment and the intensification of social contradictions. Therefore, whether for their development or preserving the host country's stability, Governments need to pay attention to financial inputs and refugees' empowerment. Although some countries have made it clear that refugees cannot enter the labor market and income-generating activities, it is not a long-term solution for refugees to survive through government aid or outside help from international organizations. As the old saying goes: "Gives the human by the fish to be inferior gives the human by the fishing." It is the key for refugees to find suitable jobs and earn income by their efforts, so employment is the basis for survival. The host country's ideal social environment is conducive to maintaining the community's self-esteem and social structure, purifying the community environment, decreasing cult invasion's effect,[26] and better managing the refugees.[27]

What is more, the management mode of communitybased management can also be used for reference by various host countries and adjusted according to their actual conditions. In urban areas, host governments should strengthen community building and implement pacification policies at the grassroots level. The government's action will facilitate closer links between community service, protection, and program functions, reduce national government personnel and international organizations' staff, and improve service efficiency.[28] Host Governments could take the following measures: promote the establishment of urban refugee associations, in particular, those for self-reliance and community support. Establishing specialized "refugee support teams" to enable suitably qualified refugee volunteers to advise their compatriots and other exiles on health, education, and GBV issues. Having the necessary professional qualifications and training for UNHCR staff working in the community service function. Indeed, these measures need to have cooperation with UNHCR. 


\section{THE ASSISTING MEASURES OF REFUGEES IN THE CIVIL WAR}

UNHCR activities in urban areas will orient towards the early attainment of durable solutions for all refugees in any other context. A suitable way will be adopted, recognizing that various refugees may benefit from various solutions. To limit the difficulties that can ensue when refugees move from camps to urban areas and from one country of asylum to another, UNHCR will strive to ensure that all refugees within a given country or region enjoy similar treatment standards and have equal access to durable solutions opportunities. Focusing on the latter principle, UNHCR's jobs for helping refugees repatriate, [29] resettle, or locally integrate will not differ in the case of urban and camp-based refugees. Simultaneously, some urban context species will bring considerable benefits to the refugees.

\section{VOLUNTARY REPATRIATION}

Because of safety and dignity, coming back home has been the most popular choice for most refugees.[30] According to the UNHCR, the level and pace of refugee returns to Syria gradually increased over the year. UNHCR verified that refugees' return was more than $75 \%$ in 2018, and inside Syria, humanitarian access to IDPs and returnees was challenging. UNHCR reached more than 1.7 million people in Syria with protection activities such as child protection and legal counseling interventions,[31] 1.8 million people with core relief items, and 520,900 people with shelter. Besides, 358,000 people got meaningful assistance through Turkey's crossborder operation.[32] Close to 383,100 Syrians returned to their country between 2017 and 2019. UNHCR does not promote refugees' returns to Syria. Returns have been spontaneous or organized by host countries or other humanitarian actors assisting returnees through the ongoing program. Since 2017, UNHCR has conducted five return perception and intention surveys among Syrians. According to these surveys, they showed that from late 2017 to early 2019, the estimated percentage of Syrian refugees hoping to return increased from 51 to 75 percent. Nevertheless, only 6 percent of those surveyed intended to return during the following 12 months. Of the remainder, only 1 in 5 designed to move to a third country, highlighting that return remains the preferred solution for most Syrians surveyed. Some 47,800 Syrians from these four countries ( 3 percent of the refugees hosted) have been resettled to a third country with UNHCR assistance during the same period.[33] Focusing on figure 7, UNHCR has made plenty of achievements in Syria refugees assisting. Concerning voluntary back to home, refugees will not be disadvantaged because they live in an urban area. UNHCR will provide information and guidance to voluntarily repatriate refugees and assist them when refugees choose to return to their country of origin, including transportation and financial assistance.[34]
"Cultural Conflict" will easily happen in the refugees who voluntarily choose to go back home, as follows: clothing, the social environment of the repatriated refugees, or the host country — dress style avant-garde fashion. Most of the people in Syria still live in a traditional style, which makes it easy for these refugees who return voluntarily to live unaccustomed; refugees enjoy more advanced infrastructure (payment platforms) in the host countries, and the construction of the country is still at a backward level, which makes it easy for the refugees to form a psychological gap. Besides, the current epidemic is prevalent. Due to power's backwardness, prevention and control measures still have a giant loophole. Many people's inflow is prone to lead to a public health crisis.

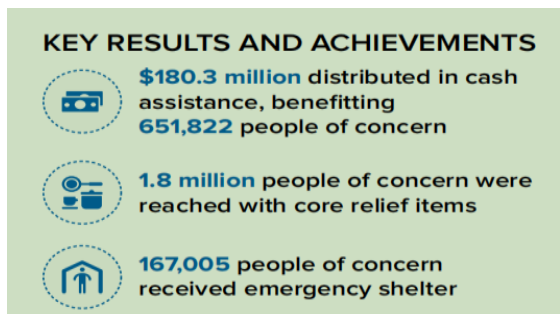

Figure 7: Resettle and Returning Refugees from 2010 to 2019.Source: UNHCR

\section{RESETTLEMENT}

Resettlement is also the primary measure in refugees' helping. [35] It is a critical tool for protecting refugees.[36] It is also a tangible mechanism for responsibility-sharing and a demonstration of solidarity, allowing States to help share each other's burdens and reduce the impact of large refugee populations on host countries. Figure 8 shows that there was only one resettlement spot available for every 20 vulnerable refugees in need at the end of this tumultuous decade. While the refugees have risen over time,[37] the number of resettlement places offered by States remained well below 100,000 between 2011 and 2013. UNHCR resettlement submissions gradually peaked at 163,000 in 2016 and dropped to almost 50 percent at about 81,000 in 2018 and 2019. Resettlement assisted refugees in countries in the past that cannot provide them with appropriate protection and support. Of all cases, more than many refugees were survivors of torture or violence, people with legal and physical protection needs, and particularly hurt women and girls[38] - just over half $(52 \%)$ of all resettlement submissions concerned children. 


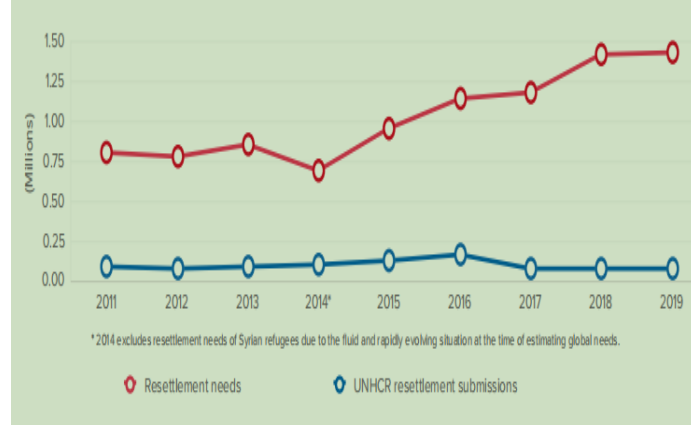

Figure 8: Gap between resettlement needs and UNHCR annual submissions.Source: UNHCR

Predictable, efficient, and effective resettlement schemes do plenty of benefit host States. Several studies published over the last decade proved that resettled refugees contribute significantly to communities' economic and social fabric. UNHCR has taken steps in resettlement: public information and media campaigns to create an environment conducive to local integration. Advocacy and technical assistance efforts to facilitate the decision of the authorities to provide naturalization legislation and procedures. Information and training for refugees. Establishing appropriate mechanisms to assess the authenticity of reported security incidents, identify individuals at risk, and intervene appropriately on their behalf. Encouraging refugees who are already in the resettlement process to remain actively involved in selfreliance and education until the process is booming, and urge them to explore alternatives where alternative solutions exist.

The resettlement of refugees is prone to "cultural conflict" too, as follows: In terms of religion, refugees believe in Islam and Allah, while many host countries believe in Catholicism and Christianity and Jesus. Many specific measures can be referred to as the regular staff assignment to visit and talk to refugees. The enhancement of communication with refugees is abundant. For example, they use mobile registration teams to contact refugees in the homes and communities. What is more, UNHCR puts much effort into collecting refugees' information by posting posters in a community center and other places that refugees gather. Also, widely disseminate itinerary registration information by the website and other social media is a good idea to have deep talks with refugees for the institution's staff.

Figure 9 shows us some vital information on refugees' assisting. From 2010 to 2019, refugees' total population is always returning higher than refugees resettled, and both changes are fluctuating. Since 2010, approximately four have repatriated for every refugee resettled. The refugees' resettlement data is in stark contrast to one for every 12 during the prior decade when almost 10 million refugees repatriated, and 810,400 refugees were resettled - a vital sign that northeast conflicts rage on without end. Based on this information, we can conclude that repatriating is decreasing over time. Returning repatriation decreases drops multiple homes may be more popular than resettled, and bearing has been the primary trend for refugees for many years.[39]

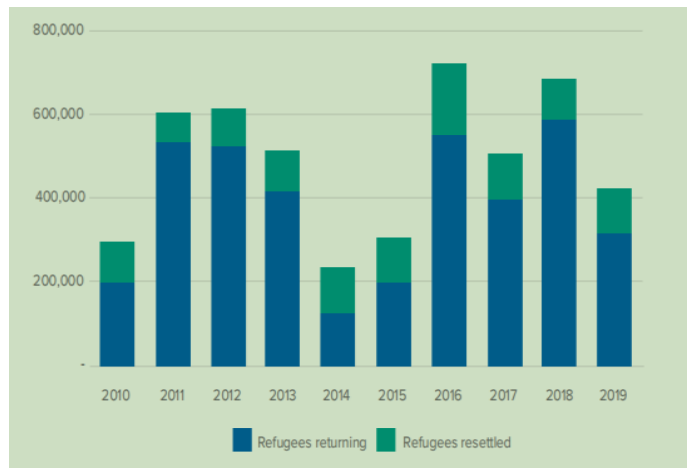

Figure 9: Key results and achievements of UNHCR assisting Syria refugees.Source: UNHCR

\section{LOCAL INTEGRATION}

The attitude of returning homes for most refugees is hopeless.[40] Except for the two methods written above, building a new life in the asylum country offers a durable solution to their plight. To integrate refugees, various kinds of institutions should proactively foster social cohesion and ensure refugees can access the job market.

Nevertheless, Globally, the integration of refugees in the labor markets remains challenging. All of these indispensable factors bring a vast challenge to refugees' work. At the same time, refugees' difficulties under such measures were close to resettlement.

\section{PROBLEMS AND DIFFICULTIES TO BE RESOLVED}

Although refugee work has been widely carried out globally for several years, saving many lives and helping many complex refugee families tide over the difficulties seem complicated. There are still too many difficulties to solve in refugee relief because of the scarcity of resources and the inevitability of war, promoting global poverty alleviation work or doing many visible jobs. Integrating refugees is vital. Suppose they remain separate and apart, with few opportunities for employment and little hope for the future - especially when linked to an ongoing, brutal war- then, a generation from now. The problem will be even harder to resolve.[41]

The relief of Syrian refugees essentially belongs to the category of social assistance. Social assistance has these features: the uniqueness of funds source, the strictness of funds application check, the oneness of duties and rights. All of them sometimes may bring negative consequences on refugees assisting. Concerning rights and obligations, when refugees cannot obtain income through their means, the UNHCR or host country provides them with material assistance utilizing relief. That is, refugees can be treated only by fulfilling or failing to fulfill their obligations, leading to unequal 
rights and obligations; in terms of funding, international organizations such as UNHCR are financed mainly by voluntary contributions from Governments and people around the world, while host countries are funded primarily bearing by national finances. However, the country's uneven development leads to a low social assistance standard. It is evident that low means of social aid in countries with common living standards and high social aid standards in countries with high living standards. This difference can easily lead to psychological imbalances among refugees who enjoy local integration or resettlement. In terms of eligibility, refugees need to submit applications to the relevant social assistance authorities of UNHCR or host countries before receiving social assistance. Then, the staff needs to review and verify refugee application materials to determine whether refugees meet the assistance standards before they can issue relief resources to refugees after verification and approval. Such a review is rigorous, easy to make refugees resentful. The negative consequence will show in the difficulties of relief and assisting relief.

\section{DATA COLLECTION AND STATISTICS}

The fact that refugees disperse in unplanned slums and that refugees prefer to help themselves rather than to inform and seek assistance from international organizations for various reasons undoubtedly makes it more challenging to collect information on refugees.

\section{THE DIFFICULTIES OF RELIEF}

UNHCR and refugees in urban areas are prone to mutual suspicion due to less communication. In particular, staff members facing resource constraints and security concerns may negatively affect refugees and relief efforts due to increased difficulty. The attitude of the staff dramatically affects the quality of assistance and the perspective of the refugees towards the UNHCR and the view of the UNHCR staff. The negative attitude of the staff will significantly attack the initiative of the refugees to seek assistance that the staff should consider forwardly find the refugees in need, which undoubtedly makes the relief more difficult.

\section{ASSISTING QUALITY}

UNHCR establishes standards or appropriate refugee relief evaluation equipment to promise data reliability. It is necessary to conduct a thorough investigation of refugees' economic situation and the pursuit of data authenticity based on relief organizations to complete correct use of varying degrees. Because of economics' rational human hypothesis, people often make selfinterest behavior to pursue the maximization of personal interests as the fundamental goal. The teams bearing homes general psychology of people gets strengthened as many subsidies as possible. Therefore, scientific evaluation methods often make refugees have considerable resentment about relief work, prompting refugees to deliberately conceal their assets and income levels. In this way, the lack of views on the coordination and utilization of resources will lead to the shortage of relief resources, exalting the stress. The organization staff is more responsible for the principle of work. Refugees review is strict, which further undermines UNHCR's relationship with refugees in urban areas.

\section{CONCLUSION}

The problem of refugees has been the great focus of countries' attention since the 20th century and Syria's fragile economy, the domestic political unrest. More importantly, Syria has become the new great powers' competition field and become an excellent power for profit to achieve sovereignty. However, because of the uncertainty and complexity of the world pattern, wars hardly stop, and the most obvious negative consequence of war is that many people lose their homes and finally become refugees. The root causes of the refugee problem are also tricky to resolve without the war's end. Therefore, if we want to promote humanitarianism and solve the refugee problem, we need the global people's join in and solve the refugee problem from a global perspective. It still needs to be put into practice for a long time in the future. Simultaneously, the international community's role should not limit the improvement of refugee groups' living conditions or the support of refugee-affected areas. Besides, they should be more flexible and economically sustainable measures. In particular, to help many countries to achieve sustainable development to the greatest extent possible, eliminating the interference of geopolitical objectives.[42]

\section{REFERENCES}

[1] UNHCR(2019), GLOBAL TRENDS: FORCED DISPLACEMENT IN 2019

[2] linkedin(2018), The Syrian conflict escalates the history of the MDI market?

[3] Xinhua News(2018-04-16), Background: The latest situation of the warring parties in Syria.

[4] Arlene Kushner(2005), The UN's Palestinian Refugee Problem

[5] Surging News (2018-04-21), NATO Airstrike and order Reconstruction in Syria.

[6] Alexios Alecou and Josefina Mavrou(2017), Refugees in Cyprus: Local Acceptance in the Past and Present

[7] https://www.renrendoc.com/p-41543000.html

[8] Ministry of Foreign Affairs of the People's Republic of China (2017-07-06), Country Profile for Syria

[9] TIMELINE(2021-02-26), At least one fighter killed in US airstrikes on Iran-backed militias in Syria

[10] US News Services(2021), Syria: Economic decline, rising hunger, and surging humanitarian needs 
[11] A Betts and others, refugee Economies, Forced Displacement and Development, Oxford University Press, 2017, page 122

[12] The People's Liberation Army (2020-12-01) Why the Syrian Refugee Crisis,page 1

[13] UNHCR(2019),TRENDS AT A GLANCE,page2

[14] Frontiers(2020-10), Is Social Contact With the Resident Population a Prerequisite of Well-Being and Place Attachment? The Case of Refugees in Rural Regions of Germany

[15] Oxford University Press(2009), UNHCR Policy on Refugee Protection and Solutions in Urban Areas

[16] UN Systems Peace, dignity and equality on a healthy planet

[17] Abdul Haq Amiri, OCHA ROMENACA(2011-09), The humanitarian challenge in the Middle East

[18] Refugee Statistics - United Nations Refugee Agency | UNHCR Canada

[19] Home | TRAFIG - Transnational Figurations of Displacement

[20] A humanitarian approach (2015-06)- The Express Tribune

[21] China Focus(2020-02): China has taken strictest measures to curb epidemic: NHC

[22] Natta, Pierfilippo M. The Diplomat; Tokyo (May 4, 2020), COVID-19 Is No Excuse to Abandon Basic Principles Protecting Refugees and Asylum Seekers,page2

[23] SUN Xiaodong and ZHANG Botao; China Human Rights(2016), The Analysis of the Refugee Determination System of China in the New International Situation

[24] Representative | UNHCR - United Nations High Commissioner for refugees

[25] WORLD ECONOMIC FORUM(2018), What are the issues facing refugee resettlement?

[26] International Business \& Economics Research Journal(2012-05), The participation of community and stakeholders in environmental Issue Management For Green Tourism In Thailand

[27] J. Edward Taylor, Mateusz J. Filipski, Mohamad Alloush, Anubhab Gupta, Ruben Irvin Rojas Valdes, and Ernesto Gonzalez-Estrada; PNAS(201607)|Economic impact of refugees

[28] THT(2020): Reduce processes and add services to benefit enterprises and people more

[29] Voluntary repatriation | UNjobs

[30] UNHCR - Protecting Refugees: questions and answers

[31] History of UNHCR Syria - UNHCR Syria

[32] UNHCR(2019), MAJOR SITUATIONS OR OPERATIONS IN THE MIDDLE EAST AND NORTH AFRICA IN 2019

[33] UNHCR(2019-03), FIFTH REGIONAL SURVEY ON SYRIAN REFUGEES' PERCEPTIONS AND INTENTIONS ON RETURN TO SYRIA

[34] THE NATIONAL ACADEMICS PRESS(2017), Application of Health Literacy to Communication with Immigrants, Refugees, and Migrants, page5360
[35] CANADIAN MUSEUM OF IMMIGRATION AT PIER 21(2020-07), 1999: Canada's Resettlement and Repatriation of Kosovar Refugees

[36] Protracted Refugee Situations - United States Department of State

[37] UNRWA - Annual report of the Director - Question of Palestine

[38] UNHCR(1993-05) - The personal security of refugees

[39] UNHCR - Solutions

[40] VOA(211-06), World Refugee Day Given Urgency by Arab

[41] Daniel Byman \& Sloane Speakman (2016) The Syrian Refugee Crisis: Bad and Worse Options, The Washington Quarterly, 39:2, 45-60

[42] Li(2020-11), Historical Development, Realistic Challenges and Innovative Paths of the Refugee Global Governance System,page19 